\title{
Applying the AcciMap methodology to investigate the tragic Mirsharai road accident in Bangladesh
}

\author{
Omar Faruqe Hamim ${ }^{1, *}$, Md. Shamsul Hoque ${ }^{1}$, Rich C. McIlroy ${ }^{2}$, Katherine L. Plant ${ }^{2}$, and \\ Neville A. Stanton ${ }^{2}$ \\ ${ }^{1}$ Department of Civil Engineering, Bangladesh University of Engineering and Technology, Dhaka, \\ Bangladesh \\ ${ }^{2}$ Transportation Research Group, University of Southampton, Southampton, UK
}

\begin{abstract}
A serious road accident happened on Monday, 11 July, 2011 afternoon in Mirsharai sub-district of Bangladesh's Chittagong district, that killed at least 44 schoolboys injured many more when the truck in which they were traveling skidded off a highway and plunged into a canal. In this study, the AcciMap methodology is applied, an extension to Rasmussen's Risk Management Framework. This sociotechnical framework provides an insight into the interactions between different levels of a system, and supports the development of recommendations that could mitigate or prevent the outcomes of such an incident in the future. In the case of Mirsharai accident, the police and social media put the blame on the truck driver alone; however, this study, based on popular media reports, accident investigation reports and local interviews revealed mismanagement and an apparent disregard for safety across different levels of the socio-technical system. By integrating the different levels of the system, from international committees to end users, the road accident scenario of Bangladesh can be improved through developing a systematic approach to accident analysis.
\end{abstract}

\section{Introduction}

The investigation of major accidents in safety-critical systems can explore a variety of contributing factors, both from within involved organizations and from dysfunctional interactions between them in a broader perspective [1]. The sociotechnical systems perspective posits that accidents are not due to the act of an isolated individual or a frontline operator, but due to highly interactive and collective processes that involve decisionmakers and policy-makers at all levels of society [2]. Given the current focus in accident analysis on the end user and immediate environment, there is a significant need for accident investigation frameworks that integrate the analysis of contributing factors from different parts of a sociotechnical system, and the interactions between them [1].

Sociotechnical methods include those such as the systems-theoretic accident model and processes (STAMP) by Leveson [3, 4], Reason's model of organizational accidents [5], and

${ }^{*}$ Corresponding author: hamim@ce.buet.ac.bd 
Rasmussen's AcciMap approach [6]. In this paper, an extension of Rasmussen's AcciMap approach [7] will be used to analyze a road accident that took place in Mirsharai, Bangladesh.

The accident at Mirsharai killed at least 44 students as a truck carrying the students drove into a ditch while the driver was reported to be talking over the phone. Police said a truck carrying 70 school students fell into a watery ditch when its driver lost control over the steering at about 1:30 pm. Relatives and locals recovered 17 bodies from the truck sunk in a nearly 6 foot deep canal.

Eyewitnesses, survivors, and locals told The Daily Star (a daily newspaper) that reckless driving was the cause of the crash. It was reported that Mofiz, a helper of the truck owned by Haji Rice Mill, was in a hurry as he was supposed to go to Feni to bring a rice consignment for the mill. "The man did not listen to repeated warnings from us and kept talking on the phone," a survivor was quoted as saying. Some other local residents alleged that the truck was overloaded and was driven by a helper, not the driver, adding that the driver escaped after the accident. Investigators found that Mofiz did not possess a valid driver's license at the time of the accident and was speaking on his mobile phone while driving. A court sentenced Mofiz to five years in jail and a fine of Tk. 20,000 ( $£ 180)$ on December 8, 2011.

The aim of this paper is to apply the AcciMap methodology to identify the higher system factors that contributed to the accident and provide some recommendations based on the sociotechnical analyses. The AcciMap approach is based on Rasmussen's risk management framework, a six-levelled, hierarchical representation of a system that not only considers the activities of actors acting in each level but more importantly, the interactions between them, which eventually take the form of decisions propagating downward and information propagating upward $[8,9,10]$.

The methodology has been used in a number of domains, including chemical processing $[11,12]$, public health [13], transportation [8, 14], aviation [9], anti-terrorism [15, 16], gas production [17], and most recently, oil and gas drilling [18]. For the purpose of this paper, an extension to Rasmussen's risk management framework was used; this included two additional upper levels, namely International Committee and National Committee (proposed by Parnell et al. [7]).

Often "a quite normal variation in somebody's behavior" can cause an accident [6]. In reality there are several factors that lead to an accident, so even if a particular factor is eradicated, it is likely another factor will cause the accident. One crucial point of consideration in this regard is to observe the actions of workers or the errors that triggered an accident in a broader sociotechnical context since those actions are impacted by the decisions and activities of other actors in all the stated levels of the system.

\section{AcciMap framework for Mirsharai road accident}

A commonly performed first step in conducting an AcciMap analysis is to identify the actors involved in the system through the development of an Actor Map. This is a graphical representation of those actors, organised by system level. The Actor Map defines all actors or organizations involved in a system. It is a method to model actors and interactions at all levels of a system. It provides a hierarchical description of a sociotechnical system. It originates from Rasmussen's Risk Management Framework [6] and can be applied to any complex domain where safety management is a concern.

The Actor Map for the Bangladesh road transport system was indeed developed, and is presented in McIlroy et al. [19]. From this, the AcciMap for the Mirsharai road accident was developed (Figure 1). Analysis started from the bottom and propagated to the top of the system. The developed AcciMap framework in Figure 1 illustrates the factors contributing 
to the Mirsharai road accident and the interrelations between them. The inter-connections between the elements of the AcciMap show where one factor leads to another factor.

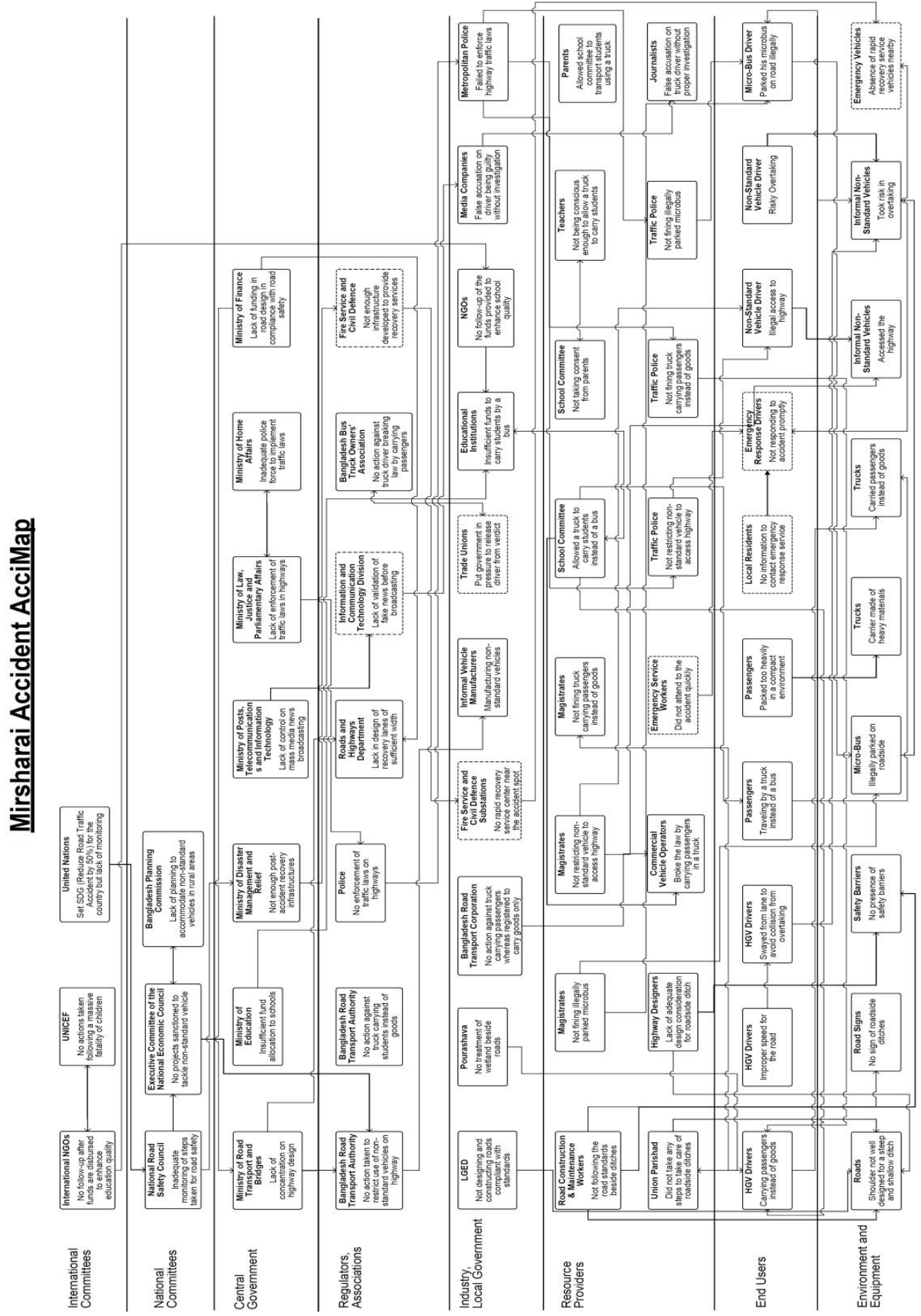

Fig. 1. AcciMap representing the various interrelated factors contributing to Mirsharai accident.

The AcciMap highlights a number of factors; truck carrying students instead of goods was moving at a high speed whilst an informal non-standard vehicle (locally called "Nasimon") was overtaking an illegally parked microbus on a two-lane two-way road. The 
truck tried to move towards the shoulder to avoid collision with the informal non-standard vehicle. There was a shallow wetland beside the road and the condition of the shoulder was poor. As a result of this, and the absence of road side safety barriers, the truck exited the carriageway and entered the shallow ditch. Due to the rigid body of the truck carrier and the shallow depth of the ditch, the students were trapped inside that carrier. Also, in the absence of nearby emergency response service, the local residents could not rescue all of the students trapped inside the truck carrier in the ditch. All of these factors lead to the death of 44 school going students.

By analyzing the sequence of events in this accident, it is evident that there are a number of higher level contributory factors. For example, the school committee allowed the students to travel to the football tournament by a truck that was not meant for human transportation; however, the school committee had insufficient funds to provide other transportation. The parents did not object to this decision. The truck that was given a route permit only to carry goods in its carrier was carrying passengers in a cramped condition, thereby violating the law; however, police and administration rarely stop vehicles illegally carrying passengers. The police also did not take any steps against the illegally parked microbus or the informal, non-standard vehicle that was illegally travelling on a regional road. Considering the contribution of the "Nasimon" (informal non-standard vehicle) in the rural economy in Bangladesh, the Planning Commission could take steps to provide feeder roads for these vehicles in rural areas in conjunction with Ministry of Road, Transport and Bridges and Local Government Department.

The local media laid all the blame on the driver for harsh driving while talking over the phone. The police arrested the driver and sentenced him to jail. No attempt was made to investigate the whole scenario and find the causal factors higher up in the sociotechnical system. As such, false allegation without proper investigation lead to blaming only the driver ignoring other factors. The flow of activities shown in the AcciMap (Figure 1) shows how one factor triggers several other factors leading to the occurrence of a disastrous accident, indicating that blame is shared across system levels, not place only on the driver.

\section{Recommendations}

A very important characteristic of the AcciMap approach is placing and matching the events and conditions that finally released the accident [1]. This characteristic avoids the unfair blame of the frontline operators, since it provides a broader perspective and background on where those events and conditions come from and what the sources of actors' decisions are [1]. The AcciMap template (8 levels) can be used to define recommendations at each level for different actors. In this section, for every event or decision that lead to the accident, a recommendation is defined (Table 1). These recommendations can be useful for legislating a systematic framework for developing a safer road system in Bangladesh.

Table 1. Recommendations corresponding to specific level of the system based on accident events.

\begin{tabular}{|c|c|c|}
\hline Level & Accident Event & Recommendation \\
\hline \multirow{7}{*}{$\begin{array}{c}\text { International } \\
\text { Committees }\end{array}$} & $\begin{array}{c}\text { Inadequate follow-up by the } \\
\text { international NGOs after } \\
\text { funds are disbursed to } \\
\text { enhance education quality }\end{array}$ & $\begin{array}{c}\text { Legislate that all funds invested by the } \\
\text { international NGOs must be monitored } \\
\text { to ensure proper allocation }\end{array}$ \\
\cline { 2 - 4 } & $\begin{array}{c}\text { Sustainable Development } \\
\text { Goal (Reduce Road Traffic } \\
\text { Accident by 50\%) was set for } \\
\text { the country but lack of } \\
\text { monitoring failed the }\end{array}$ & $\begin{array}{c}\text { Legislate that proper monitoring } \\
\text { system must be present for all targets } \\
\text { set by international organizations }\end{array}$ \\
\hline
\end{tabular}




\begin{tabular}{|c|c|c|}
\hline Level & Accident Event & Recommendation \\
\hline & achievement of the target & \\
\hline \multirow{7}{*}{$\begin{array}{l}\text { National } \\
\text { Committees }\end{array}$} & $\begin{array}{l}\text { National Road Safety Council } \\
\text { took insufficient monitoring } \\
\text { steps for ensuring road safety }\end{array}$ & $\begin{array}{l}\text { Develop a framework for monitoring } \\
\text { the road safety programs }\end{array}$ \\
\hline & $\begin{array}{l}\text { Executive Committee of the } \\
\text { National Economic Council } \\
\text { sanctioned insufficient } \\
\text { projects to tackle non- } \\
\text { standard vehicle intrusion } \\
\text { into roads } \\
\end{array}$ & $\begin{array}{l}\text { Develop a rehabilitation program to } \\
\text { relocate the non-standard vehicles } \\
\text { from the highways and stop their } \\
\text { intrusion }\end{array}$ \\
\hline & $\begin{array}{l}\text { Bangladesh Planning } \\
\text { Commission has not } \\
\text { portrayed any plans to } \\
\text { accommodate non-standard } \\
\text { vehicles in rural areas }\end{array}$ & $\begin{array}{l}\text { Non-standard vehicles have a major } \\
\text { contribution to the flourishing } \\
\text { economy of rural people, so there } \\
\text { should be planning for feeder roads in } \\
\text { rural areas to ensure the use of non- } \\
\text { standard vehicles }\end{array}$ \\
\hline & $\begin{array}{c}\text { Ministry of Education } \\
\text { allocate insufficient funds to } \\
\text { rural schools } \\
\end{array}$ & $\begin{array}{c}\text { Adequately resource essential school } \\
\text { transport (e.g. shared bus for use in a } \\
\text { multi-school district) }\end{array}$ \\
\hline & $\begin{array}{l}\text { Ministry of Home Affairs has } \\
\text { limited police force to } \\
\text { enforce traffic laws }\end{array}$ & $\begin{array}{l}\text { Police force must be enriched with } \\
\text { more skilled traffic policemen for } \\
\text { better implementation of traffic laws }\end{array}$ \\
\hline & $\begin{array}{l}\text { BRTA has taken minimal } \\
\text { action against the truck } \\
\text { carrying students instead of } \\
\text { goods }\end{array}$ & $\begin{array}{l}\text { BRTA must cancel the driving license } \\
\text { of drivers disobeying laws and getting } \\
\text { involved in accidents }\end{array}$ \\
\hline & $\begin{array}{l}\text { Police do not enforce traffic } \\
\text { laws properly in highways }\end{array}$ & $\begin{array}{l}\text { Develop a monitoring cell which will } \\
\text { look up the activities of traffic police }\end{array}$ \\
\hline \multirow{4}{*}{$\begin{array}{l}\text { Industry and Local } \\
\text { Government }\end{array}$} & $\begin{array}{l}\text { LGED (Local Government } \\
\text { Engineering Department) } \\
\text { roads are inadequately } \\
\text { designed and constructed in } \\
\text { compliance with standards in } \\
\text { accordance with the traffic } \\
\text { volume }\end{array}$ & $\begin{array}{l}\text { Proper design methods and technology } \\
\text { must be developed by research and } \\
\text { strictly enforce monitoring system in } \\
\text { construction stage }\end{array}$ \\
\hline & $\begin{array}{l}\text { Pourashava does not treat } \\
\text { wetlands beside roads }\end{array}$ & $\begin{array}{l}\text { Proper treatment must be provided to } \\
\text { roads adjacent to wetlands and ditches }\end{array}$ \\
\hline & $\begin{array}{l}\text { Informal non-standard } \\
\text { vehicles are being } \\
\text { manufactured locally }\end{array}$ & $\begin{array}{c}\text { Rules for use of informal non-standard } \\
\text { vehicles only in rural areas must be } \\
\text { made by BRTA }\end{array}$ \\
\hline & $\begin{array}{l}\text { Media made false accusation } \\
\text { on driver being guilty without } \\
\text { any investigation }\end{array}$ & $\begin{array}{l}\text { Provision should be made to enforce } \\
\text { strict punishment for false allegation } \\
\text { by media without investigations }\end{array}$ \\
\hline \multirow{3}{*}{ Resource Providers } & $\begin{array}{c}\text { Magistrates did not fine } \\
\text { illegally parked microbus, } \\
\text { truck carrying passengers } \\
\text { instead of goods and non- } \\
\text { standard vehicle that accessed } \\
\text { the highway }\end{array}$ & $\begin{array}{l}\text { Develop a framework to facilitate } \\
\text { routine monitoring of road activities by } \\
\text { magistrates to fine any illegal activities } \\
\text { made by the road users }\end{array}$ \\
\hline & $\begin{array}{l}\text { School committee allowed a } \\
\text { truck to carry students instead } \\
\text { of a bus without taking } \\
\text { consent from parents }\end{array}$ & $\begin{array}{l}\text { Legislate that no trucks or any vehicle } \\
\text { designed to carry goods can carry } \\
\text { passengers for any purpose }\end{array}$ \\
\hline & $\begin{array}{l}\text { Teachers and parents allowed } \\
\text { the students to be carried by a }\end{array}$ & $\begin{array}{l}\text { Create social awareness about the } \\
\text { hazardous effects of transporting }\end{array}$ \\
\hline
\end{tabular}




\begin{tabular}{|c|c|c|}
\hline Level & Accident Event & Recommendation \\
\hline & truck & people via trucks \\
\hline \multirow{3}{*}{ End Users } & $\begin{array}{c}\text { Truck driver was carrying } \\
\text { passengers instead of goods } \\
\text { at a high speed with respect } \\
\text { to the class of the road }\end{array}$ & $\begin{array}{l}\text { Strict enforcement must be followed } \\
\text { for punishing drivers carrying } \\
\text { passengers in a vehicle designed to } \\
\text { carry goods and high speed driving }\end{array}$ \\
\hline & $\begin{array}{l}\text { Non-standard vehicle driver } \\
\text { illegally accessed the } \\
\text { highway and got involved in } \\
\text { risky overtaking }\end{array}$ & $\begin{array}{c}\text { Provide proper training to non- } \\
\text { standard vehicle drivers to make them } \\
\text { literate about the traffic rules and } \\
\text { regulations }\end{array}$ \\
\hline & $\begin{array}{c}\text { Micro-bus driver illegally } \\
\text { parked his microbus on road }\end{array}$ & $\begin{array}{c}\text { Incorporate provisions of emergency } \\
\text { vehicle stop bays in highways }\end{array}$ \\
\hline \multirow{3}{*}{$\begin{array}{c}\text { Equipment and } \\
\text { Environment }\end{array}$} & $\begin{array}{c}\text { Shoulders are not designed } \\
\text { for steep and shallow ditch } \\
\text { beside roads }\end{array}$ & $\begin{array}{l}\text { Design roads with proper care taken } \\
\text { for roadside ditches }\end{array}$ \\
\hline & $\begin{array}{l}\text { Road traffic signs were not } \\
\text { present for road side ditches } \\
\text { or speed limit }\end{array}$ & $\begin{array}{l}\text { Provide adequate road signs and } \\
\text { ensure its proper maintenance }\end{array}$ \\
\hline & $\begin{array}{l}\text { Safety barriers were not } \\
\text { present }\end{array}$ & $\begin{array}{l}\text { To reduce fatalities from road } \\
\text { accidents, safety barriers must be } \\
\text { provided }\end{array}$ \\
\hline
\end{tabular}

\section{Conclusion}

This paper describes the application of AcciMap methodology for investigating the Mirsharai road accident, identified as one of the most tragic accidents that has happened in the road traffic accident history of Bangladesh. For any road accident, a proper and detailed accident investigation accompanied with a systematic, sociotechnical framework of analysis that takes into account higher system factors, provides benefit over traditional investigation approaches. From the AcciMap analysis presented in this article, the root causes of the accident were identified that go beyond blaming only the driver. The possible links between the causes that incurred the accident were also duly recognized. The responsible factors at every level of the sociotechnical system are marked and corresponding recommendations have been proposed. These recommendations will be vital for any future road safety intervention in Bangladesh, and to future accident investigation activities.

\section{Acknowledgments}

This research was commissioned by the National Institute for Health Research using Official Development Assistance (ODA) funding. The views expressed are those of the authors and not necessarily those of the NHS, the NIHR, or the Department of Health and Social Care.

\section{References}

1. Lee, S., Moh, Y. B., Tabibzadeh, M., Meshkati, N., 2017. Applying the AcciMap methodology to investigate the tragic Sewol Ferry accident in South Korea. Applied Ergonomics, 59, 517-525.

2. Le Coze, J.E., 2015. Reflecting on Jens Rasmussen's legacy. a strong program for a hard problem. Saf. Sci. 71, 123-141. Part B. 
3. Leveson, N., 2004. A new accident model for engineering safer systems. Saf. Sci. 42 (4), 237-270.

4. Leveson, N., 2011. Engineering a Safer World: Systems Thinking Applied to Safety. The MIT Press.

5. Reason, J., 1997. Managing the Risks of Organizational Accidents. Ashgate Publishing Limited.

6. Rasmussen, J., 1997. Risk management in a dynamic society: a modeling problem. Saf. Sci. 27 (2), 183-213.

7. Parnell, K.J., Stanton, N.A., Plant, K.L., 2017. What's the law got to do with it? Legislation regarding in-vehicle technology use and its impact on driver distraction. Accident Analysis and Prevention, 100, 1-14.

8. Rasmussen, J., Svedung, I., 2000. Proactive Risk Management in a Dynamic Society, first ed. Raddningsverket, Risk and Environmental Department. Swedish Rescue Services Agency, Karlstad, Sweden.

9. Branford, K., 2011. Seeing the big picture of mishaps: applying the AcciMap approach to analyze system accidents. Aviat. Psychol. Appl. Hum. factors 1 (1), 31-33.

10. Salmon, P.M., Cornelissen, M., Trotter, M.J., 2012. Systems-based accident analysis methods: a comparison of Accimap, HFACS, and STAMP. Saf. Sci. 50, 1158-1170.

11. CSB Final Investigation Report, 2015. Chevron Richmond Refinery Pipe Rupture and Fire: Chevron Refinery\#4 Credit Unit. US Chemical Safety and Hazard Investigation Board. Report No. 2012-03-I-CA.

12. CSB Report, 2014. Catastrophic Rupture of Heat Exchanger: Tesoro Anacortes Refinery. US Chemical Safety and Hazard Investigation Board. Report No. 2010-08I-WA.

13. Vicente, K.J., Christoffersen, K., 2006. The walkerton E. coli outbreak: a test of Rasmussen's framework for risk management in a dynamic society. Theor. Issues Ergonomics Sci. 7, 93-112.

14. Underwood, P., Waterson, P., 2014. Systems thinking, the Swiss cheese model and accident analysis: a comparative systemic analysis of the grayrigg train derailment using the atsb, AcciMap and STAMP models. Accid. Analysis Prev. 68, 75-94.

15. Jenkins, D.P., Salmon, P.M., Stanton, N.A.,Walker, G.H., 2010. A systemic approach to accident analysis: a Case Study of the Stockwell Shooting. Ergonomics 53, 1-17.

16. Waterson, P.E., Jenkins, D.P., 2011. Lessons learnt from using AcciMaps and the risk management framework to analyse large-scale systemic failures. In: Anderson, M. (Ed.), Contemporary Ergonomics and Human Factors 2011: Proceedings of the International Conference on Ergonomics \& Human Factors 2011, Stoke Rochford, Lincolnshire. CRC Press, p. 6. April 12-14, 2011.

17. Hopkins, A., 2000. Lessons from Longford: the ESSO Gas Plant Explosion. CCH, Sydney, Australia.

18. Tabibzadeh, M., Meshkati, N., 2015, April 27e30. Applying the AcciMap Methodology to Investigate a Major Accident in Offshore Drilling: a Systematic Risk Management Framework for Oil and Gas Industry. SPE-174020-MS. SPE Western Regional Meeting. Society of Petroleum Engineers, Garden Grove, CA.

19. McIlroy, R.C., Plant, K.A., Hoque, M.S., Jianping, W., Kokwaro, G.O., Vũ, \& N.H, Stanton, N.A., 2019. Who is responsible for global road safety? A cross-cultural comparison of Actor Maps. Accident Analysis and Prevention, 122, 8-18. 